\title{
THE UNDERSTANDING OF FACTS IN JUDICIAL PROCESS: AN ANALYSIS FROM THE ISLAMIC PERSPECTIVE ${ }^{1}$
}

\author{
Mohd Badrol Awang ${ }^{1}$ \\ Senior Lecturer, Faculty of Law \& International Relations, \\ (UniSZA), Malaysia \\ (Email: badrolawang@unisza.edu.my) \\ Aminuddin Mustaffa ${ }^{2}$ \\ Senior Lecturer, Faculty of Law \& International Relations, \\ (UniSZA), Malaysia \\ (Email: aminuddin@unisza.edu.my) \\ Mohd Lotpi Mohd Yusob ${ }^{3}$ \\ Lecturer, Faculty of Law \& International Relations, \\ (UniSZA), Malaysia \\ (Email: mohdlotpi@unisza.edu.my) \\ Naziree Md. Yusuf ${ }^{4}$ \\ Lecturer, Faculty of Law \& International Relations, \\ (UniSZA), Malaysia \\ (Email: naziree@unisza.edu.my) \\ Nor Aida Abd. Kadir 5 \\ Lecturer, Faculty of Law \& International Relations, \\ (UniSZA), Malaysia \\ (Email: aidakadir@unisza.edu.my) \\ Nazli bin Ismail @ Nawang6 \\ Senior Lecturer, Faculty of Law \& International Relations, \\ (UniSZA), Malaysia \\ (Email: inazli@unisza.edu.my)
}

Accepted date: $22-02-2019$

Published date: 10-07-2019

To cite this document: Awang, M. B., Mustaffa, A., Yusob, M. L. M., Md. Yusuf, N., Kadir, N. A. A., \& Ismail Nawang, N. (2019). The Understanding of Facts in Judicial Process: An Analysis from The Islamic Perspectives . International Journal of Law, Government and Communication, 4(15), 71-83.

DOI: $10.35631 /$ ijlgc. 415008

\begin{abstract}
The importance of understanding the factual reality (fahm al-waqi') has been extensively discussed by Muslim jurists in their discussion pertaining to Islamic legal theory. It has been accepted as an important component for the practice of ijtihad and recognized as a valid justification for renewal of ijtihad. In light of the above, yet in a different setting, the paper discusses the concept of al-da' $w a$ and the significance of understanding the fact of a legal dispute (fahm al-da 'wa) in Islamic trial process. It examines the significance of fahm alda'wa by the trial judge in the trial process. The study proves that the understanding of the facts of the cases assumes a very critical position in the trial process, the laxity of which will
\end{abstract}

\footnotetext{
${ }^{1}$ This paper was originally presented at the $5^{\text {th }}$ International Conference on law and Society in Mei, 2016 at University of Patoni, Thailand. The paper was funded by a Special Research Grant Scheme managed by Research Management, Innovation \& Commercialization Centre (RMIC), Sultan Zainal Abidin University.
} 
affect the propriety of judicial decisions and thus leading to injustice. Further, the paper argues that the kind of facts that need to be ascertained and understood by the trial judges are not limited to the specific occasions of the cases, rather the general circumstances and the reality of the living conditions of the times need also to be taken into consideration. Finally, the paper avers that the requirement to understand the facts of the cases necessitates a kind of undertaking in the nature of ijtihad which is to be carried out by all judges regardless of their status whether they are mujtahid (jurist) or muqallid (imitator).

Keywords: Understanding of Facts, Judicial Process, Islamic Perspective

\section{Introduction}

It has been established that there are three important constituents of a trial process that judges must direct their minds in order to arrive at judicial judgments. They are; the facts, the evidence proving the facts, and the governing law. ${ }^{2}$ Accordingly, the facts of judicial claims ( $a l-d a$ ' $\left.a w a\right)$ become one of the essential ingredients that need to be attended to by judges during the judicial proceedings. Judges cannot decide cases of dispute unless and until the facts of the cases have been comprehensively understood and proven. ${ }^{3}$ Being that in mind, the current study discusses the concept of the claim ( $a l-d a ' w a)$ towards the end of establishing the importance of understanding the facts of the claims in the trial process. The discussion pertaining to the facts is very important not only due to the reason that the facts are a compulsory element in a judicial process, rather that the understanding of the facts itself is influential in the formulation of the judicial judgments. The overall discussion of the study will provide insight as to the criticality of understanding facts of dispute which eventually will help the judge to decide the disputes, as well as the kind of facts need consideration of the judges while adjudicating judicial disputes. The study argues that the endeavour to understand the facts of legal cases constitutes an effort of ijtihad in nature.

The Judicial Concept of A Claim (Al-Da' $\mathrm{Wa})$ : A Reflection of The Factual Jurisprudence The Arabic term $a l-d a$ ' $w a$ which literally means a claim or a charge ${ }^{4}$ has been afforded with many definitions by Muslim jurists and scholars. ${ }^{5}$ Muhammad Na'im Yasin, while deliberating those various definitions of $a l-d a a^{\prime} w a$, has come out with his own definition of al-da' $w a$. He defines $a l-d a$ ' $w a$ as "the accepted words or anything else taking the place of words in a judicial proceeding, which are intended to mean that a person is claiming or securing a right for himself or for his principal". 6 This definition has been accepted by some scholars as representing the most comprehensive definition of $a l-d a$ ' $w a$ reflecting distinctively the true nature of $a l-d a$ ' $w a$ in its practical sense. ${ }^{7}$ Notably, that the definition has clarified some important points

\footnotetext{
2 Capurso, Timothy J, “How Judges Judge: Theories on Judicial Decision Making”, Law Forum, vol. 29 no. 1(1998), p. 9.

${ }^{3}$ Ibn al-Qayyim al-Jawziyyah, I lam al-Muwaqqi in, v.1, (Qahirah:Dar al-Hadith,2006), p. 75.

${ }^{4}$ Sa'di Abu Jayb, al-Qamus al-Fiqhi, (Damshiq: Dar al-Fikr, 1988), p. 130.

${ }^{5} \mathrm{~A}$ collection of definitions of $a l-d a$ ' $w a$ from the four Islamic schools of thought can be seen in Mahmud Muhammad Nasir Barakat, al-Sultah al-Taqdiriyyah li al-Qadi fi al-Fiqh al-Islami, ('Amman: Dar al-Nafais, 2007), p. 180.

${ }^{6}$ Muhammad Na'im Yasin, Nazariyyah al-Da'wa bayna al-Shari'ah al-Islamiyyah wa Qanun al-Murafa'at alMadaniyyah wa al-Tijariyyah, (Jordan: Dar al-Nafa'is, 2005), p. 75-84.

${ }^{7}$ Mahmud Saedon A. Othman, An Introduction to Islamic Law of Evidence, translated from Malay language by Raden Ahmad Shauki R. Hisam (Shah Alam: HIZBI, 1996), p. 20-21, Mat Noor Mat Zain, "Pendakwaan dalam Islam", in Al-Syariah: Kehakiman Islam, edited by Siti Zalikhah Md. Nor and et al. (Kuala Lumpur: Dewan Bahasa \& Pustaka, 2004), p. 99, the definition has also been quoted in Mahmud Muhammad, al-Sultah..., p. 180.
} 
respecting the essential constituents of a claim; that it must be made in words or expressed in writing or by understandable signs, that it must be made in a judicial proceeding and that the claim must fulfil all conditions prescribed by the law. ${ }^{8}$

From the definition, it is clear that the purpose of instituting a claim or a charge is to demand or to secure or to protect a right or an interest against another. It can be brought up by the person entitled to the right or by his representative to the Court as one of the dispute settlement agencies established for that purpose by the state. However, for the claim to be recognised by the Court it inevitably must fulfil the requirements of a valid claim according to the law.

It is also fairly obvious that by defining a claim or a charge ( $a l-d a$ ' $w a)$ as "accepted words or anything else taking place of words" positively indicates that a claim or a charge rests upon a factual account of what had happened between the parties. For, usually, a claim or a charge is preceded by an account of facts leading to the claim or the charge. There is no claim or charge which is devoid of facts. A claim or a charge normally starts when two or more individuals interact with one another or when an individual infringes the community's right. ${ }^{9}$ Therefore, bringing up a claim or a charge for Court's consideration is a process of bringing up a certain set of facts for Court deliberation in order to determine the right or interest of the parties to the action.

The support for supposing a claim ( $a l-d a$ ' $w a)$ as a matter of fact can also be ascertained from the saying of the Prophet (S.A.W.) as narrated by Umm Salamah that the Prophet (S.A.W.) says;
"You bring to me for (judgment) your disputes, some of you perhaps being more eloquent in their plea than others, so I give judgment on their behalf according to what $I$ hear from them. (bear in mind, in my judgment) if I slice off anything for him from the right of his brother, he should not accept that, for I slice off for him a portion from the Hell." 10

The statement of the Prophet (S.A.W.) that he decided the case based on what he heard from the parties shows that the Prophet (S.A.W) decided the case based on what he knew about the facts and the proof of the claim $(a l-d a ' w a)$ that had been presented by the parties before him. ${ }^{11}$ This is because the presentation of the facts of a claim ( $a l-d a ' w a)$ and its proof have been made mandatory by the Prophet (S.A.W.) in another hadith reported by Ibn 'Abbas which says to the effect that;

"If the people were given according to their claims, they would claim the lives of persons and their properties, but the oath must be taken by the defendant." 12

\footnotetext{
${ }^{8}$ For conditions of a valid claim or charge, refer to Mahmud Muhammad, al-Sultah..., p. 180-201, Mahmud Saedon, An Introduction..., p. 23-25 and Mat Noor, "Pendakwaan...", p. 101-105.

9 Steven J. Burton, An Introduction to Law and Legal Reasoning, (United States of America: Aspen Law \& Business, 1995), p. 11.

${ }^{10}$ Muslim al-Naysaburi, Sahih Muslim: Kitab al- 'Aqdiyyah, hadith no. 1713, vol. iii, p.149.

${ }^{11}$ Ruzman Md. Noor, "Penulisan Teks Penghakiman dari Aspek Keterangan di Mahkamah Syariah", in Penulisan Teks Penghakiman di Mahkamah Syariah, edited by Ruzman Md. Noor (Kuala Lumpur: Penerbit Universiti Malaya, 2008), p. 53.

${ }^{12}$ Muslim al-Naysaburi, Sahih Muslim: Kitab al-Aqdiyah, hadith no. 1711, vol. iii, p.149.
} 
The combined reading of the above two hadiths proves that the essence of a claim ( $a l-d a$ ' $w a)$ is but an account of the factual set of circumstances or situations which lead up to an action in the Court against another person. In this regard, the facts of the case form the basis to initiate a claim for a right or an interest recognized by the law. Accordingly, a claim (al-da'wa) is essentially a matter of facts. However, the claim ( $\left.a l-d a^{\prime} w a\right)$ must be supported by sufficient and verified evidence before the same can be granted.

\section{The Importance of Understanding the Facts of Cases in The Trial Process: A Manifestation of Factual Ijtihad (Al-Ijtihad Fi Al-Waqi')}

In a trial process, understanding the facts of cases is inevitably mandatory. Besides, it is regarded as the most important process to be exercised by the trial judge. It is because the judgment of the trial judge must be constructed on the basis of the application of the governing law to the facts of the cases. ${ }^{13}$ Thus, the trial judge must make his best efforts to arrive at the correct understanding of the facts of the cases brought for his adjudication otherwise he would err in his judgment. ${ }^{14}$ Apart from that and as a consequence, the judgment arrived at by the trial judge on the mistaken understanding of the facts is also liable to be set aside. ${ }^{15}$ Perhaps, it is in this conjunction that Muhammad bin Husayn al-Jizani, a contemporary scholar, stresses the importance of comprehensive understanding of the facts of cases when he said that most of the mistakes in the process of formulating legal rules for unprecedented cases (figh al-nawazil) ${ }^{16}$ are due to the lack of correct and comprehensive understanding of the circumstances and concomitants of the case and not due to the lack of knowledge regarding the governing legal rules. ${ }^{17}$

The above statement has its support from the observation of Imam al-Shatibi who has long before argued that almost all legal issues had been duly examined and settled by the Muslim jurists, due to which a mere imitation (taqlid) in the law might suffice to solve legal problems. Accordingly, what is important is to analyze and verify the facts of a given case in light of its governing rules or principles in order to come to a proper legal conclusion. This is because, alShatibi reasoned, that the facts of legal cases (nawazil) are always new or unique (musta'nifah) and have no exactly similar precedent. Even if the cases have seemingly similar precedent in the past, it cannot be ascertained that the cases are completely similar with the precedent justifying the giving of the same ruling until a meticulous examination (al-nazr) has been made to the facts of the cases, which is in itself an undertaking in the nature of ijtihad. ${ }^{18}$

Thus, ijtihad in the trial process should not be understood to revolve around the issues relating to the ascertainment of the applicable legal rules alone aloof from the concerns regarding the facts of the case. Even, the correctness and propriety of judicial judgments have been argued

\footnotetext{
${ }^{13}$ Mujahid al-Islam al-Qasimi, al-Nizam al-Qada'i al-Islami, translated from Hindi by Nur al-Haq al-Rahmani, (Beirut: Dar al-Kutub al-'Ilmiyyah, 2001), p. 165.

14 Ibn Qayyim al-Jawziyyah, Shams al-Din Abu 'Abd Allah Muhammad bin Abi Bakr bin Ayyub (d.751H/1350M), Bada' $i$ ' al-Fawa'id, edited by 'Ali bin Muhammad al-'Imran, (n.p: Dar 'Alim al- al-Fawa'id, n.d.), vol. 4, p. 1318-1319.

15 Al-Qasimi, p. 165.

${ }^{16}$ Fiqh al-Nawazil is a term used to describe the jurisprudential discussion of making ijtihad to determine legal rules for unprecedented cases including the legal cases decided by judges. See, Muhammad bin Husayn al-Jizani, Fiqh al-Nawazil: Dirasah Ta'siliyyah Tatbiqiyyah, (al-Mamlakah al-'Arabiyyah al-Su'udiyyah: Dar ibn al-Jawzi, 2008), vol. 1, p. 20.

${ }^{17}$ Ibid., p.64.

${ }^{18}$ Al-Shatibi, Abu Ishaq Ibrahim, al-Muwafaqat fi Usul al-Shari 'ah, edited by 'Abd Allah Darraz, (Kaherah: Dar al-Hadith, 2006), vol. 4, p. 363, Ahmad Hasan, Analogical Reasoning in Islamic Jurisprudence: A Study of the Juridical Principle of Qiyas, (New Delhi: Adam Publishers \& Distributors, 2007), p. 357.
} 
to depend substantially on the correct understanding of the facts and circumstances of the case. ${ }^{19}$ In this connection, it is clear that ijtihad in the fact-finding process is central and indispensable forming part of the overall ijtihad undertaking of the trial judge in the trial process.

In light of the above and to further illustrate the centrality of understanding the facts of a case, a reference may be made to the analysis of Imam al-Shatibi regarding the sayings of the Prophet (S.A.W.) which are outwardly in contradiction to one and another. In his analysis of the varied sayings of the Prophet (S.A.W.) offering inconsistent answers regarding the best deeds to be performed by believers when asked by the Companions, Imam al-Shatibi argued that the answers were different in order to reflect the peculiarity of times, conditions and inquirers of each incident. Likewise, Imam al-Shatibi presented the same justification when the Prophet (S.A.W.) was reported to have prayed for the abundance of wealth to Anas, but the Prophet (S.A.W.) refused to pray the same for Tha'labah bin Hatib when he asked the Prophet (S.A.W.) to do so. Instead, the Prophet (S.A.W.) replied "The less for which you can give thanks is better than the more for which you are unable to give thanks". ${ }^{20}$ Thus, these sayings of the Prophet (S.A.W.) are, in reality, not in contradiction to each other, instead they stand as concrete proofs evidencing a great legal acumen and profound reflection of the Prophet (S.A.W.) in dealing with every legal case. ${ }^{21}$

Similarly, in the issue of kissing one's wife during the day of fasting, the Prophet (S.A.W.) was reported to have given contradictory answers to two different inquirers. In response to this, Shaykh 'Ali al-Khafif observed that the Prophet (S.A.W.) answered differently taking into consideration the different status of the inquirers. The Prophet (S.A.W.) prohibited the first inquirer since he was a young man fearing that he would not be able to hold himself whereas the Prophet (S.A.W.) allowed the second inquirer, an old man who would normally be able to control himself and would not go beyond the act of kissing. ${ }^{22}$ This shows that the Prophet (S.A.W.) had taken into consideration the facts of the cases, including the background of the inquirers, before making his rulings for the specific issues or cases before him.

In the context of a trial process, the above explanation strongly suggests that there are situations where the applicable laws for the cases at hand are very well clear and simple. However, to determine whether the cases are governed by the dictates of their governing laws and thus to be assigned with the same rulings still requires an intensive and considerable analysis by the judge of the facts of the cases. In addition, the analysis of the judges might lead towards different legal conclusions or judicial judgments although a same governing law or rule has been applied to decide cases of dispute. In this regard, a reference may be made to the instructive statement of Imam al-Shafi' $i$ who observed that in adjudicating a case, it is possible for a trial judge to allow the claim in the case while another judge decides otherwise. According to him, such a difference is acceptable as long as each of them had acted in accordance with his judicial responsibility. ${ }^{23}$

\footnotetext{
${ }^{19}$ See, Ibn Qayyim, Bada'i‘..., vol. 4, p. 1318-1319, Wail bin 'Abd Allah bin Sulayman al-Huwayrini, Manhaj $f i$ Istinbat al-Ahkam al-Nawazil, (al-Riyad: Maktabah al-Rushd, 2012), p. 268.

${ }^{20}$ Al-Shatibi, al-Muwafaqat..., vol. 4, p. 368-369, Ahmad Hassan, Analogical Reasoning..., p. 360.

${ }^{21}$ Al-Shatibi, al-Muwafaqat..., vol. 4, p. 368-369.

22 'Ali al-Khafif, Muhadarat fi Asbab Ikhtilaf al-Fuqaha', (n.p., 1956), p. 83-84.

${ }^{23}$ Al-Shafi‘i, al-Risalah, Edited by Ahmad Muhammad Shakir,(Kaherah:Maktabah Dar al-Turath, 1979), p. 503.
} 
To further explain the necessity of making a serious consideration on the facts of the case despite already being clear regarding its governing law, the illustration made by Lon L. Fuller might be very enlightening. He demonstrated the application of a very straight forward rule providing that "No person shall sleep in the city park" in two different sets of fact. The first, where a guy was found sitting upright on a park bench at noon, with his chin was resting on his chest, his eyes were closed, and the guy was snoring audibly. In the second case, a disheveled tramp was found lying on the same bench at midnight with a pillow beneath his head, and a newspaper was spread over his body as a blanket. The tramp, however, had insomnia. Both were arrested and brought for trial before a Court of law. As the judge trying the cases, what would be your decision in both situations? Would you convict the guy and acquit the tramp or vice versa or that you would convict both or acquit both? Whatever your decision, does it base on the language of the rule alone or due to the difference of the facts of the cases. ${ }^{24}$

The above discussion and illustration of cases explain very well the significance of ijtihad in the understanding of the facts of the cases in the trial process. Obviously, the determination of the rightful party in a civil dispute or the verdict of guilty of an accused in a criminal proceeding substantially depends on the correct understanding and thorough reflection of the trial judge of the facts of the case. ${ }^{25}$

In 'Umar al-Khattab's letter of Islamic Judiciary, he had instructed Abu Musa al-Ash'ari that the latter must truly understand the facts of the disputes before making any judicial judgment. The relevant part of the letter reads:

"Hence, you must understand when the case is presented to you..."26

Commenting on the above instruction, Ibn Qayyim al-Jawziyyah observed that there are two kinds of understanding that a judge must have in order to come to a correct judgment. One of them is the correct and profound understanding of the factual circumstances of the case and the ability to uncover the real facts from the signs and the evidence of circumstances. Another one is the understanding of the rule governing the factual situations of the case that is the understanding of God's ruling in His Book or from His Messenger (S.A.W.). ${ }^{27}$ Obviously, the first kind of understanding underlines the understanding of the facts and circumstances of the case which will help the judge to come to a just and correct decision. ${ }^{28}$ According to Ibn Qayyim al-Jawziyyah, those who strain their utmost effort on these two understanding will surely be entitled to two or one rewards. ${ }^{29}$ In the words of Ibn Qayyim al-Jawziyyah, he observed the following:

"Neither the mufti nor the judge is capable of a correct fatwa or judgment (al$h u k m)$ unless with two kinds of understanding. One of them is the understanding of the facts of the incident ( $a$-waqi ${ }^{\circ}$ ) and to have a deep understanding of it and be able to deduce the reality of what happened through circumstances ( $\mathrm{al}$ -

\footnotetext{
${ }^{24}$ Lon L. Fuller, "Positivism, and Fidelity to Law: A Reply to Professor Hart", Harv. L. Rev. vol. 71, (1958), p. 662. See also Steven J. Burton, p. 19.

${ }^{25}$ Mahmud Muhammad, al-Sultah..., p. 443.

${ }^{26}$ Ibn al-Qayyim, I'lam..., vol. 1, p. 75.

${ }^{27}$ Ibid., p. 77.

${ }^{28}$ Mahmud Saedon, Institusi..., p. 70.

${ }^{29}$ Ibn al-Qayyim, I'lam..., vol. 1, p. 77.
} 
qarinah), indications (al-'amarat) and signs (al-'alamat) to the extent he has comprehensive knowledge of the incident. The second understanding is the understanding of what is obligatory (al-wajib) for that incident, that is, to understand the ruling of Allah (hukm Allah) which he has prescribed (hakama bihi) in His Book or upon the words (lisan) of His Messenger for the incident..." 30

\title{
Uniqueness of Facts
}

The great emphasis on the importance of having a deep and thorough understanding of the facts of every case is also justifiable on the ground that each case or dispute has its own peculiar set of facts. As stated before, according to al-Shatibi the facts of legal cases (nawazil) are always unique (musta'nifah) with no precisely similar examples. Even if the cases have seemingly similar precedents in the past, it cannot be ascertained that the cases are absolutely similar justifying the same ruling until a thorough examination (al-nazr) on the facts of the cases has been conducted. ${ }^{31}$

In addition, Steven J. Burton, a Professor of Law of University of Iowa, in his description of the uniqueness of every case brought for the determination of the Court, has written the following words:

\begin{abstract}
"Treating a case as a short story of an incident emphasizes that every case is unique in all of its particulars. A case involves two or more parties, both of whom are unlikely ever to repeat the very action that led to the dispute between them. We can describe the events in one case in terms general enough to encompass other disputes between other parties in other times and places. We can also describe them in terms specific enough to encompass only the dispute that occurred between these parties at one time and place. However we describe cases, each occurs once." 32
\end{abstract}

It is probably on the above understanding that Shaykh Mahmud Shaltut stressed that everything that came from the Prophet (S.A.W.) in his capacity as a judge is categorized as the general legislative Sunnah which is not strictly binding on the Muslims. He argued that the actions of the Prophet (S.A.W.) in the exercise of his judicial functions were utterly based on his ijtihad as a trial judge. ${ }^{33}$ This is a trite principle because it was narrated to the effect that the Prophet (S.A.W.) had decided cases based on the presentation of facts and evidence by the parties before him personally. ${ }^{34}$

Reflecting the proceedings in the trial process, normally the facts of the case will be presented to the trial judge personally, who will have the opportunity to hear the facts of the case directly from the parties and their witnesses. The judge also has the chance to observe the manoeuvre and demeanour of the witnesses and to ask questions in order to seek for further clarification on the matters that are unclear to him. In such situations and upon being clear of the facts of the case, the judge is expected to decide the case based on his understanding and analyses of

\footnotetext{
${ }^{30}$ Ibid.

${ }^{31}$ Al-Shatibi, al-Muwafaqat..., vol. 4, p. 363, Ahmad Hassan, Analogical..., p. 357.

${ }^{32}$ Steven J. Burton, p. 12.

${ }^{33}$ Mahmud Shaltut, p. 500.

${ }^{34}$ Al-Shawkani, Nayl..., vol. 8, no. hadith 3909, p. 638, also Muslim al-Naysaburi, Sahih Muslim, (Kaherah: Muassasah Zad, 2012), hadith no. 1713, p. 568.
} 
the facts and evidence presented during the trial process. This means that the judge should not, in such circumstances, blindly follow the opinions of the others regardless of their learning and knowledge or to allow them to decide the case. Such recourse would amount to injustice as the others are not privy to the trial process and in ignorance of the facts of the case.

Apparently, in any judicial dispute, the facts of the case constitute a vital element that the proper understanding of the facts will lead to the right ascertainment of the governing law and its application to the facts of the case and hence a correct judgment. In this conjunction, it is strongly relevant to quote the words of Ibn Qayyim al-Jawziyyah who said that:

"...the knowledgeable (al- 'alim) (of the mufti or qadi) is one who arrives, by his knowledge of the factual circumstances of the case (al-waqi $\left.{ }^{\circ}\right)$ and his erudition (al-tafaqquh) of its ruling, to the knowledge of the ruling of Allah and His Messenger (S.A.W.)..."35

Thus, it is argued that a blind imitation to the opinions of the others or a slavish dependence on the previously decided cases is not an acceptable approach in the Islamic trial process. To let the other persons to decide the case or to follow blindly their opinions without making a proper analysis regarding the applicability of the facts of the case to its governing law is not a justice. Accordingly, it is the trial judge who needs to determine according to his ijtihad whether the proven facts of the case constitute a proper occasion for the application of the governing law to the facts of the case. In that sense, it is clear that the facts of the case become the determining factor in the applicability of the law to the specific occasion of the case. The judicial undertaking of the judge to understand and analyse the facts of cases is, in fact, a manifestation of al-ijtihad fi al-waqi which is to be exercised mandatorily by every trial judge regardless whether he is a jurist (mujtahid) or an imitator (muqallid). ${ }^{36}$

It is worthwhile in order to sum up the whole discussions to quote the written statement of Shaykh al-Lahaydan, the former president of the Supreme Judicial Council of Saudi Arabia, when he wrote that:

"It is incumbent on every qadi that he practices ijtihad in the case that is before him and seeks (yataharra) the truth and asks his colleagues and his shaykhs if the matter is obscure to him. This is a relative ijtihad, because each case has its circumstances and concomitants, and the situations that compel it and the causes that bring about its situations..." 37

\section{The Kind of Facts to Be Considered by The Judges}

We have duly pointed out in the preceding discussions that legal cases ( $\left.d a^{\prime} a w a\right)$ are matter of facts which are unique in each case. Due to that, it is justified to regard every case as a novel case whereby judges are required to exercise their ijtihad as to the circumstances of the case (ijtihad fi al-waqi ${ }^{\circ}$ ) in order to truly comprehend the case.

\footnotetext{
${ }^{35}$ Ibn al-Qayyim, I'lam..., vol. 1, p. 77.

${ }^{36}$ Ibn Qudamah, Muwaffaq al-Din Abu Muhammad, Rawdah al-Nazir wa Jannah al-Munazir fi Usul al-Fiqh 'ala al-Imam Ahmad bin Hanbal. (Riyad: Maktabah al-Rushd, 1993), vol. 2, p. 229-232.

37 This written statement had been recorded in Vogel, Frank Edward, "Islamic Law and Legal System in Saudi Arabia", (Ph.D thesis, Harvard University, 1993), p. 317.
} 
In addition, as far as trial process is concerned, it has been accepted as a trite principle of law that the kind of facts that need to be considered in trial process must be either the facts in issue or relevant facts only. The facts in issue and the facts relevant (qarinah) to the facts in issue have been defined, for example in section 3 of the Syariah Court Evidence (Federal Territories) Act 1997 (Act 561) in the following words:

"fact in issue" means any fact from which, either by itself or in connection with other facts, the existence, non-existence, nature or extent of any right, liability or disability asserted or denied in any suit or proceeding necessarily follows;

\section{ILLUSTRATION}

$A$ is charged for an offence of khalwat with $B$.

At his trial the following facts may be in issue:

that $A$ and $B$ were together in a closed room;

that $A$ and $B$ were together in a vehicle parked in a dark place;

"qarinah" means fact connected with the other fact in any of the ways referred to in this Act;

Based on the above definition, the facts in issue in a legal action are those facts that the claimant or the prosecution must prove for his claim to be allowed as well as those facts that the defendant or the accused must prove for his defence to succeed. ${ }^{38}$ In light of this, facts in issue are substantially determinable by referring to the substantive law or the provision of law governing the legal actions. For example, in a criminal case of committing an act preparatory to sexual intercourse out of wedlock, section 24 of Syariah Criminal Offences (Federal Territories) Act 1997 (Act 559) provides the following law:

Any person who does an act preparatory to sexual intercourse out of wedlock shall be guilty of an offence and shall on conviction be liable to a fine not exceeding three thousand ringgit or to imprisonment for a term not exceeding two years or to both.

Based on the provision, the facts in issue that need to be established are that the accused have not been legally married to each other and that the accused's act constitutes an act which is preparatory to the commission of sexual intercourse.

Implying that the accused, in their defence to the charge, claim that they are husband and wife, then a new fact in issue arises which will justify for the introduction and admission of the relevant facts proving the marriage. The alleged marriage, if sufficiently proven, would establish the defence that the accused are husband and wife.

Similarly, in a civil claim for variation of children maintenance order on the ground that there has been material change in the circumstances relating to the need of the children, for example, under section 75 of Islamic Family Law (Federal Territory) Act 1984 (Act 303). ${ }^{39}$ The facts in

\footnotetext{
${ }^{38}$ Ruzman, "Penulisan..., p. 57. See also Ashgar Ali Ali Mohamed, (ed.), The Annotated Statutes of Malaysia: Syariah Court Evidence (Federal Territories) Act 1997 (Act 561), (n.p.: LexisNexis, 2009), p. 153.

${ }^{39}$ The section provides that the Court may, on the application of any interested person, at any time and from time to time vary, or at any time rescind, any order for the custody or maintenance of a child, where it is satisfied that
} 
issue that must be proved by the applicant for the claim to be allowed are that there has been significant change in the need of the children for example, due to the increase in their age or due to their physical disability needing special care justifying an increase in the maintenance order and that the increase applied for is reasonable taking into account the current need of the children and the capability of the defendant father to sustain the new maintenance order.

The facts relevant to the issue (qarinah), on the other hand, are those facts that are related to the facts in issue from which the existence or non-existence of the facts in issue could be determined by way of implication. ${ }^{40}$ As far as the Malaysian evidence enactments are concerned, the relevant facts (qarinah) have been statutorily provided in the provisions of those enactments. ${ }^{41}$

In addition, it is instructive to highlight herewith the exemplary approach of 'Umar al-Khattab in taking into account the prevailing social and economic facts in the society in deciding legal cases. An illustrative example of this judicial approach can be examined in the case of theft committed in the famine year ( 'am al-ramadah), whereby 'Umar al-Khattab decided to suspend its punishment. It is well-known that the provision of law regarding the offence of theft in the Qur'an is clear. The Qur'an prescribes that the punishment for the offence of theft is amputation of the thief's hand. ${ }^{42}$ In that particular case, however, the caliph did not mete out the punishment as prescribed taking into consideration the facts of the famine and the hardship of the time. ${ }^{43}$ In fact, there is no provision in the Qur'an or in the Sunnah recognizing the state of famine or drought as a basis for suspending the punishment for committing theft. It was 'Umar's perspicuous judgment to suspend the punishment in such a situation applying his sense of justice and taking into consideration the prevalent social facts and the need of the people. This excellent interpretative ijtihad of 'Umar then becomes the basis for the ruling of the Muslims jurists that the punishment of theft can be suspended during times of difficulty such as economic crisis, famine and prolonged drought, all of which refer to the facts of the society in which the law is going to be applied. ${ }^{44}$

The decision of 'Umar al-Khattab to regard triple divorce (talaq) in a single occasion as constituting irrevocable three divorces (talaqs) is another clear example where the societal facts had been considered as relevant facts in deciding legal cases. It is well-known that at the time of the Prophet (S.A.W.) and Abu Bakr al-Siddiq the pronouncement of a triple divorce in a single occasion was considered as affecting a single divorce (talaq) only. However, 'Umar alKhattab had amended the law on the basis of the prevailing circumstances of the time. It has been recorded that the move of 'Umar al-Khattab was mostly due to the Muslims attitude who were hurried in pronouncing talaq in playful manners. There were cases where a husband divorced his wife with one hundred or even one thousand talaqs which were considered as a form of mockery to the Quranic teaching. 'Umar al-Khattab then decided to introduce the new

the order was based on any misrepresentation or mistake of fact or where there has been any material change in the circumstances.

${ }^{40}$ Adrian Keane \& Paul McKeown,The Modern Law of Evidence, (New York: Oxford University Press, 2010), p. 7-8.

${ }^{41}$ See, sections 6 to 16 of the Syariah Court Evidence (Federal Territories) Act 1997 (Act 561).

42 Al-Qur'an, (al-Maidah:38)

${ }^{43}$ Ibn Qayyim, I'lam..., vol. 2, p.11.

${ }^{44}$ Muhammad Yousuf Faruqi, "Modes of Ijtihad in the Judgments of the Khulafa' al-Rashidun", Intellectual Discourse, vol. 1, no. 1, (October 1993), p. 13. However, the concession should only be made available to the accused who is really affected by the difficult situations, for example if a rich person committed theft during the times of difficulty, he should not be let free on the basis of the difficulty. See, Ibn Qayyim, I'lam ..., vol. 2, p. 12. 
law as a form of $t a$ ' zir (discretionary) penalty in order to regulated the attitude of the people so that the people would be more cautious and thoughtful before pronouncing talaqs. ${ }^{45}$ The reason for the change in the law has in fact been reported clearly in the Imam Muslim's collection where it was reported that:

"Ibn 'Abbas (Allah be pleased with them) reported that the (pronouncement) of three divorces during the lifetime of Allah's Messenger (may peace be upon him) and that of Abu Bakr and two years of the caliphate of 'Umar (Allah be pleased with him) (was treated) as one. But 'Umar al-Khattab (Allah be pleased with him) said: Verily the people have begun to hasten in the matter in which they are required to observe respite. So, if we had imposed this upon them, and he then, imposed it upon them."46

The above example of cases clearly establish that the judges must consider not only the facts in issue and the relevant facts which are specific to the occasions or incidents of the cases, but also the social facts prevailing in the society which have immediate relevancy or impact in deciding the cases, in term of politics, economy, as well as cultures and habits. In light of the above, when deciding the status of triple divorce in one sitting, apart from considering the status of the divorce itself as the most disapproved permissible thing, the controversial status of triple divorces, the historical development of the law of triple divorce (talaq), the underlying purpose and interest of the approach adopted by 'Umar al-Khattab to regard the divorce as effecting three divorces, as well as the highly-probable outcome of the decision to the parties and their families, the judges must also direct their judicial consideration to the present attitude of the Malaysian Muslim society towards divorce; whether they regard divorce as a simple issue and treat it in a playful manner; the issue which had become the basis for 'Umar alKhattab to amend the law of triple divorce.

\section{Conclusion}

The above explanation establishes that factual accounts constitutes an important element of a judicial claim ( $\left.a l-d a^{\prime} w a\right)$. Accordingly, the facts of the case need to be thoroughly ascertained and understood by the judge during the judicial proceedings. In addition, the paper establishes that the kind of facts that need to be ascertained and understood by the trial judges are not limited to the facts that are specific to occasions of the cases only, rather the general circumstances and the reality of the living conditions of the times need to be taken into account as well in deciding legal cases. Apparently, the discussion in the paper highlights the importance of understanding the facts of the cases, which is, upon reflection, reflective to the concept of ijtihad fi al-waqi as discussed by Muslim jurists. As far as the trial process is concerned, the requirement to understand the facts of the cases applies to all judges regardless of their status, mujtahids or muqallids.

\section{References}

Al-Huwayrini, Wa'il bin 'Abd Allah bin Sulayman. (2012). al-Manhaj fi Istinbat Ahkam alNawazil. Riyad: Maktabah al-Rush.

\footnotetext{
${ }^{45}$ Yusuf al-Qaradawi, al-Siyasah al-Shar 'iyyah fi Dhaw' Nusus al-Shari 'ah wa Maqasidiha. (Kaherah: Maktabah Wahbah, 1998), p. 212, Muhammad Firdaus Nurul Huda, Kesan Perubahan Sosial Terhadap Hukum Islam, (Selangor: Thinker`s Library, 2002), p. 222.

${ }^{46}$ www.ium.edu.my/deed/hadith/muslim/009_smt.html: Translation of Sahih Muslim Book: Kitab Talaq (The Book Of Divorce)Chapter 2: Pronouncement of Three Divorces(Book 9, Number hadith 3491)
} 
Al-Jizani, Muhammad bin Husayn. (2008). Fiqh al-Nawazil: Dirasah al-Ta'siliyyah Tatbiqiyyah ( $3^{\text {rd }}$ edn.). vol. 4. al-Mamlakah al-'Arabiyyah al-Su'udiyyah: Dar al-Jawzi.

Al-Mawardi, Abu al-Hasan 'Ali bin Muhammad ibn Habib al-Ansari. (2006). al-Ahkam alSultaniyyah. Ed. by Ahmad Jad. Kaherah: Dar al-Hadith.

Al-Naysaburi, Muslim Ibn al-Hajjaj al-Qushayri. (1999). Sahih Muslim. (Abdul Hamid Siddiqi, Trans.). India: Adam Publisher \& Distributors.

Al-Naysaburi, Muslim Ibn al-Hajjaj al-Qushayri. (2012). Sahih Muslim. Kaherah: Mu'assasah Zad.

Al-Qaradawi, Yusuf. (1994). al-Ijtihad al-Mu'asir bayna al-Indibat wa al-Infirat. Kaherah: Dar al-Tawzi‘ wa al-Nash al-Islamiyyah.

Al-Qaradawi, Yusuf. (1996). al-Ijtihad fi al-Shari 'ah al-Islamiyyah. Kuwait: Dar al-Qalam.

Al-Qaradawi, Yusuf. (1998). al-Siyasah al-Shar 'iyyah fi Daw' al-Shari 'ah wa Maqasidiha. Kaherah: Maktabah Wahbah.

Al-Qasimi, Mujahid al-Islam. (2001). al-Nizam al-Qada'i al-Islami. (Nur al-Haq al-Rahmani, Trans.). Beirut: Dar al-Kutub al-'Ilmiyyah.

Al-Sajistani, Abu Dawud Sulayman ibn al-Ash'ath. (1984). Sunan Abi Dawud. (Ahmad Hassan, Trans.). Lahore: Ashraf Press.

Al-Shatibi, Abu Ishaq Ibrahim bin Musa. (2006). al-Muwafaqat fi Usul al-Shari 'ah. vol. 4. Ed. by 'Abd Allah Darraz. Kaherah: Maktabah Dar al-Hadith.

Al-Shawkani, Muhammad ibn 'Ali Muhammad. (2004). Nayl al-Awtar. vol. 8. Kaherah: Dar Ibn al-Haythami.

Al-Syafi‘i, Muhammad bin Idris. (1979). al-Risalah. Ed. by Ahmad Muhammad Shakir. Kaherah: Maktabah Dar al-Thurath.

Adrian Keane \& Paul McKeown. (2010). The Modern Law of Evidence. New York: Oxford University Press.

Ashgar Ali Ali Mohamed. (ed.). (2009). Annotated Statutes of Malaysia: Syariah Court Evidence (Federal Territories) Act 1997 (Act 561). n.p.: LexisNexis.

Capurso, Timothy J. (Fall 1998). How Judges Judge: Theories on Judicial Decision Making. Law Forum, vol. 29(1), pp. 5-15.

Ibn Qayyim al-Jawziyyah, Shams al-Din Abu 'Abd Allah Muhammad bin Abi Bakr bin Ayyub. (2004). I'lam al-Muwaqqi in 'an Rabb al-'Alamin. vol. 2. Ed. by 'Isam al-Din alSababiti. Kaherah: Dar al-Hadith.

Ibn Qayyim al-Jawziyyah, Shams al-Din Abu 'Abd Allah Muhammad bin Abi Bakr bin Ayyub. (n.d.). al-Turuq al-Hukmiyyah fi al-Siyasah al-Syar 'iyyah. Ed. by Muhammad Jamil alGhazi. Jeddah: Dar al-Madani.

Ibn Qayyim al-Jawziyyah, Shams al-Din Abu 'Abd Allah Muhammad bin Abi Bakr bin Ayyub (n.d.). Bada'i ' al-Fawa'id. vol. 4. Ed. by 'Ali bin Muhammad al-'Imran. n.p: Dar 'Alim al- al-Fawa'id.

Lon L. Fuller. (1958). Positivism and Fidelity to Law: A Reply to Professor Hart. Harv. L. Rev. vol. 71, pp. 630-664.

Ibn Qudamah, Muwaffaq al-Din Abu Muhammad. (1993). Rawdah al-Nazir wa Jannah alMunazir fi Usul al-Fiqh 'ala al-Imam Ahmad bin Hanbal. Riyad: Maktabah al-Rushd.

Mahmud Saedon A. Othman. (1996). An Introduction to Islamic Law of Evidence. (Raden Ahmad Shauki R. Hisam, Trans.). Shah Alam: HIZBI.

Mat Noor Mat Zain. (2004). Pendakwaan dalam Islam. In Siti Zalikhah Md. Noor (ed.), AlSyariah: Kehakiman Islam (pp. 98-134), vol. 2. Kuala Lumpur: Dewan Bahasa \& Pustaka.

Mohammad Hashim Kamali. (2007). Principles of Islamic Jurisprudence. (2 ${ }^{\text {nd }}$ edn.). Selangor: Ilmiah Publisher. 
Muhammad Firdaus Nurul Huda. (2002). Kesan Perubahan Sosial Terhadap Hukum Islam. Selangor: Thinker`s Library.

Muhammad Na'im Yasin. (2005). Nazariyyah al-Da'wa bayna al-Shari 'ah al-Islamiyyah wa Qanun al-Murafa 'at al-Madaniyyah wa al-Tijariyyah. Jordan: Dar al-Nafa'is.

Muhammad Yousuf Faruqi. (October 1993). Modes of Ijtihad in the Judgments of the Khulafa al-Rashidun. Intellectual Discourse, vol. 1(1), p. 9-27.

Mahmud Muhammad Nasir Barakat. (2007). al-Sultah al-Taqdiriyyah li al-Qadi fi al-Fiqh alIslami. Amman: Dar al-Nafais.

Peters, Rudolph. (2002). From Jurists' Law to Statute Law or What Happens When the Shari'a is Codified. Mediterranean Politics, vol. 7, no. 3, pp.82-95.

Ruzman Md. Noor. (2008). Penulisan Teks Penghakiman dari Aspek Keterangan di Mahkamah Syariah. In Ruzman Md. Noor (ed.), Penulisan Teks Penghakiman di Mahkamah Syariah (pp. 53-67). Kuala Lumpur: Penerbit Universiti Malaya.

Sa'di, Abu Jayb. (1988). al-Qamus al-Fiqhi. Damshiq: Dar al-Fikr.

Vogel, Frank Edward. (May 1993). Islamic Law and Legal System in Saudi Arabia. DoctoralThesis, Harvard University. 